Historic, Archive Document

Do not assume content reflects current scientific knowledge, policies, or practices. 
Lake, Spencer County, Indiana:- iditur

Genuine guaranteed Catalpa Speciosa or hardy Catalpa seed from the largest forest trees in the Ohio Valley bottoms. We guarantee these seeds to be true Catalpa Speciosa. They have been pronounced Catalpa Speciosa by the Forestry Service.

We are now making a special price of $75 \mathrm{c}$. per pound. With an order of ten pounds we give instructions how to grow Catalpa Speciosa Seedilings.

If you are interested and want to buy in quantities write us for our discounts for large quantities and for cash. We require cash with orders for ten pounds or less. Satisfactory reference before shipment for larger orders.

We are now ready to contract to grow genuine Catalpa Speciosa seedlings for fall and winter delivery of 1914 in any quantities. Also Black Locust.

We will furnish the various grades at the following prices:

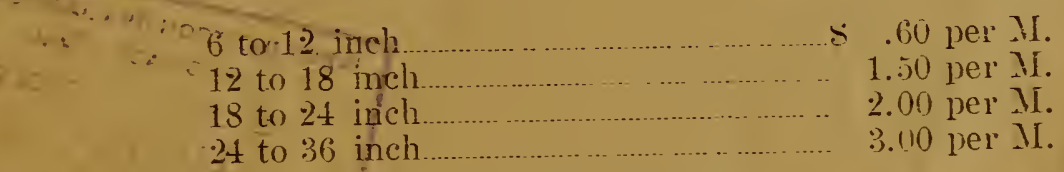

Apples: Grafted, tro rears-All standard varieties.

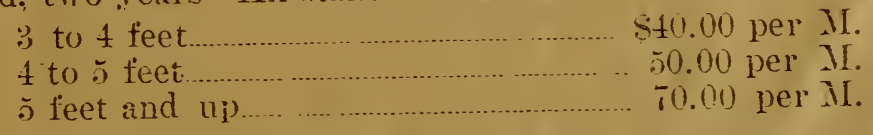

Peaches: Budded, rearlings-All standard rarieties.

2 to 3 fect
3 to $t$ feet
t tet and up. on per M.

ack Walnut:

1 feet and up

6 to 8 feet .......................................

Soft Maple:

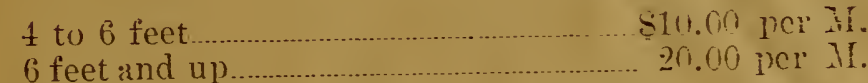

California Privet: two-year-old, well rooted and branched.

12 to 19 inch
18 to 24 inch

Black Locust:

\begin{tabular}{|c|}
\hline $\begin{array}{l}6 \text { to } 12 \text { inch } \\
12 \text { to } 24 \text { inch.. }\end{array}$ \\
\hline
\end{tabular}

Catalpa Speciosa Seedlings:

6 to 12 inch....
12 to 18 inch

$\$ .70$ per $\lambda$. 2.00 per 3.

18 to 24 inch

Carolina Poplar:

6 to 8 feet $\ldots \ldots \ldots \ldots \ldots \ldots$ per $M$.

Paragon Seedling Chestnuts:

Chestnuts:

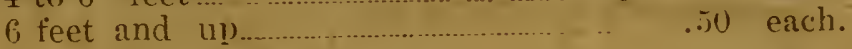

Spanish Chestnut:

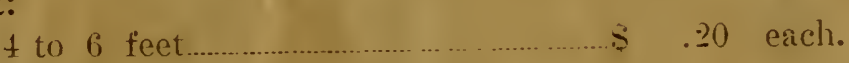

Basket Willow Cuttings:

$\$ \quad 1.50$ per M.

\section{Root Grafted Pecans:}

We have .00 root grafted pecans. Varieties as follows: Indiana. Busseron. Grayrille or Posey, Buttrick, Luce, Warrick, Kentuck. and Walters.

$$
\begin{aligned}
& \text { Two rear old: } 2 \text { to } 4 \text { feet............... S } \$ 2.00 \text { each. } \\
& 1 \text { to } 2 \text { feet } \ldots \ldots \ldots . . . . . . . . . . . .51 .50 \text { each. } \\
& \text { One rear old: } 1 \text { to } 2 \text { feet .............................. } \\
& \text { Boxes and Bags extra. }
\end{aligned}
$$

We fumigate when requested or required. 
